\title{
Effects of Phosphorus Fertilization and Plant Spacing on Herbage Yield of Groundnut (Arachis hypogaea L.) in Bauchi State, Nigeria
}

\author{
Shuaibu Y. M. , Sabo M. U., Isah Y. \\ Department of Crop Production, Faculty of Agriculture and Agricultural Technology, Abubakar Tafawa Balewa University, Bauchi, Nigeria \\ Email: ymshuaibu@atbu.edu.ng
}

Received: 29 July 2020; Revised: 28 October 2020; Accepted: 28 October 2020

\begin{abstract}
A field trial was conducted at Bauchi State university teaching and research farm Gadau during 2018 and 2019 rainy seasons, to study the effects of phosphorus fertilization and plant spacing on herbage yield of groundnut. The treatments consisted of four levels of phosphorus fertilizer $\left(0,30,60\right.$ and $\left.90 \mathrm{~kg} \mathrm{P}_{2} \mathrm{O}_{5} / \mathrm{ha}\right)$ and three spacing $(20 \times 60 \mathrm{~cm}$, $25 \times 60 \mathrm{~cm}$ and $30 \times 60 \mathrm{~cm}$ ), factorially combined to give 12 treatments and laid out in a Randomized Complete Block Design $(\mathrm{RCBD})$ replicated three times. The results of the experiment showed a significant $(\mathrm{P}<0.01)$ difference among the treatments used throughout the study period. The result also revealed that, application of 60 and $90 \mathrm{~kg}_{2} \mathrm{O}_{5} /$ ha were observed to be statistically similar but significantly $(\mathrm{P} \leq 0.05)$ recorded the highest number of branches, canopy spread, biomass, stover and pod yield than the other treatments used. However, all treatments were better than the control. In terms of spacing however, widest spacing $(30 \times 60 \mathrm{~cm})$ significantly $(\mathrm{P} \leq 0.05)$ gave the highest number of branches and canopy spread than the other spacing used. The result further indicated that, closest spacing $(20 \times 60 \mathrm{~cm})$ recorded the highest biomass and stover yields throughout the study period. Years of study on the other hand, 2019 was proved to be significantly better than 2018 in all the characters observed. Based on the result of this findings, it can be concluded that, application of 60 to $90 \mathrm{~kg} / \mathrm{ha} \mathrm{P}_{2} \mathrm{O}_{5}$ and closest spacing $(20 \times 60 \mathrm{~cm})$ gave the highest biomass and stover yields and is recommended to farmers for groundnut herbage production in the study area.
\end{abstract}

Keywords: fertilizer, canopy, branch, biomass, stover

\section{Introduction}

Groundnut is one of the world's most popular crops cultivated throughout the tropical and sub-tropical areas where annual precipitation is between 1000-1200 mm for optimum growth of the crop. The crop is native to South America, Mexico and Central America [1]. Leading world producers of the crop are China, India, Nigeria, USA and Senegal. Nigeria ranks third among the major producers [2]. The Nigeria's total output of the crop in 2018 was 6.48 million metric tons [3]. Groundnut has high economic and nutritional potential and is an important cash crop for peasant farmers in tropical countries including Nigeria. Industrially, the oil produced from the kernels is used for manufacturing of lubricants and other items ranging from shaving cream and soap to plastics. The seedcake has been used for livestock feed and fertilizer and shells have been utilized as filter for wallboard and insulators [4]. In Nigeria like other developing countries where the crop is grown, groundnut is an excellent food, containing about $60 \%$ highly digestible protein, $22 \%$ carbohydrate, $4 \%$ minerals and about $8 \%$ fat [5]. The groundnut plays an extremely important agronomic

Copyright (C)2020 Shuaibu Y. M., et al.

DOI: https://doi.org/10.37256/jba.112021555

This is an open-access article distributed under a CC BY license

(Creative Commons Attribution 4.0 International License)

https://creativecommons.org/licenses/by/4.0/ 
role in the traditional farming systems as a nitrogen fixer in crop rotations [6]. Commercial production of groundnut in Nigeria is concentrated in the northern parts of the country particularly in areas between the Northern Guinea and Sudan Savanna zones [7]. This study was therefore carried out to determine the best spacing and phosphorus fertilization for the production of groundnut herbage in Bauchi state, Nigeria.

\section{Materials and methods}

A field trial was conducted at Bauchi State University teaching and research farm Gadau during 2018 and 2019 wet seasons, to study the effect of phosphorus fertilization and plant spacing on herbage yield of groundnut. The recommended phosphorous fertilizer for groundnut in Nigeria is $50 \mathrm{~kg} / \mathrm{ha}$. The treatments consisted of four level of phosphorus fertilizer $(0,30,60$ and $90 \mathrm{~kg} / \mathrm{ha})$ and three spacing $(20 \times 60 \mathrm{~cm}, 25 \times 60 \mathrm{~cm}$ and $30 \times 60 \mathrm{~cm})$, factorially combined to give 12 treatments combination and laid out in a Randomized Complete Block Design (RCBD) replicated three times. A composite soil sample $(0-30 \mathrm{~cm}$ depth) was collected from experimental site before the onset of the experiment. The sample was analyzed for texture, $\mathrm{pH}$, organic carbon, total $\mathrm{N}$ and available P. Exchangeable bases such as $\mathrm{Ca}, \mathrm{Mg}, \mathrm{K}$ and $\mathrm{Na}$ were also determined (Table 1). The experimental site was cleared and ridges were prepared manually using simple hand tools. The groundnut seeds (SAMNUT 26) was sown on June 28, 2018 and June 12, 2019 with two seeds per hole. Phosphorous fertilizer was applied twice; first dose during planting and the second dose at six weeks after planting. All cultural practices including refilling, thinning, pest and disease control were carried out. Data was collected at bi-weekly interval on number of branches and canopy spread, whereas biomass, stover and pod yields were measured at the end of the experiment. All data collected were subjected to combine analysis of variance and means were separated using Duncan's Multiple Range Test (DMRT).

Table 1. Physicochemical properties of the soil at experimental site within $0-30 \mathrm{~cm}$ depth

\begin{tabular}{ccc}
\hline Physical properties & & \\
\hline Sand $(\mathrm{g} / \mathrm{kg})$ & 808.0 & \\
Silt $(\mathrm{g} / \mathrm{kg})$ & 27.2 & \\
Clay $(\mathrm{g} / \mathrm{kg})$ & 164.8 & \\
Texture & Sandy loam & Rank $/$ Grade \\
\hline Chemical properties & & Moderate acidic \\
Soil pH 1:2 (H2O) & 5.80 & Low \\
Organic carbon & 1.38 & Moderate \\
Organic matter (\%) & 2.34 & Medium \\
Total N (\%) & 0.21 & Low \\
Available P (mg/kg) & 8.63 & \\
Exchangeable bases $(\mathrm{Cmol} / \mathrm{kg})$ & & Low \\
$\mathrm{Ca}$ & 2.68 & Low \\
$\mathrm{Mg}$ & 0.63 & Medium \\
$\mathrm{K}$ & 0.27 & Low \\
$\mathrm{Na}$ & 0.13 & \\
\hline
\end{tabular}

\section{Results and discussion}

\subsection{Number of branches}

Table 2 presented result on the effects of phosphorous fertilization, plant spacing and year on number of branches. The result revealed a significant difference among the treatments used throughout the study period. The results further 
showed that, except at 4 weeks after sowing (WAS) where application of $60 \mathrm{~kg} / \mathrm{ha}$ produced higher number of branches than $90 \mathrm{~kg}$, application of 60 and $90 \mathrm{~kg} / \mathrm{ha}$ were found to be statistically similar throughout the study period but significantly better than the lesser rates and all the rates were better than the control. The significant difference observed in this study indicated the importance of phosphorous fertilization towards enhancing number of branches of groundnut. The result of this experiment is in conformity with the findings of [8] who reported a positive response of number of branches of groundnut with increasing level of phosphorus fertilizer. The present findings also lend support to the report of [9] that, increasing phosphorus fertilizer level promote number of branches in groundnut.

Considering various spacings used, the result showed that, except at 4 WAS where no significant difference was observed, wider spacing was proved to be statistically better throughout the study period. This observation is in line with the findings of [10] who observed that, under wider spacing in groundnut there could be more feeding zones which may have encouraged lateral growth resulting in the production of more branches per plant. It is also in agreement with the result of [11] who noted that, close spacing led to intensification of inter plant competition and reduce the root zone which could result in lower number of branches per plant.

Year of study on the other hand, better branches were observed in 2019 than 2018 rainy season. Interaction of phosphorous and year as presented in Table 3 revealed that, application of 60 and $90 \mathrm{~kg} / \mathrm{ha}$ in 2019 were statistically at par but produced higher number of branches than the other treatments and when applied in 2018 rainy season. This could be attributed to accumulation of phosphorous fertilizer from the previous year, there by making it more available in the soil. The result of this findings concur with the report of [9], who noted that continues application of fertilizer leads to its accumulation and availability in the soil.

Table 2. Effects of phosphorus fertilization and plant spacing on number of branches of groundnut

\begin{tabular}{|c|c|c|c|c|c|}
\hline \multirow[b]{2}{*}{ Treatments } & \multicolumn{5}{|c|}{ WAS } \\
\hline & 4 & 6 & 8 & 10 & 12 \\
\hline \multicolumn{6}{|c|}{ Phosphorous (kg/ha) } \\
\hline 0 & $3.99^{\mathrm{c}}$ & $5.53^{\mathrm{c}}$ & $7.52^{\mathrm{c}}$ & $10.51^{\mathrm{c}}$ & $11.69^{c}$ \\
\hline 30 & $4.52^{\mathrm{b}}$ & $6.60^{\mathrm{b}}$ & $8.57^{\mathrm{b}}$ & $11.48^{\mathrm{b}}$ & $12.66^{\mathrm{b}}$ \\
\hline 60 & $4.83^{\mathrm{a}}$ & $8.27^{\mathrm{a}}$ & $10.24^{\mathrm{a}}$ & $13.24^{\mathrm{a}}$ & $14.45^{\mathrm{a}}$ \\
\hline 90 & $4.56^{\mathrm{b}}$ & $8.32^{\mathrm{a}}$ & $10.31^{\mathrm{a}}$ & $13.32^{\mathrm{a}}$ & $14.51^{\mathrm{a}}$ \\
\hline LS & $* *$ & $* *$ & $* *$ & $* *$ & $* *$ \\
\hline $\mathrm{SE} \pm$ & 0.07 & 0.05 & 0.05 & 0.07 & 0.07 \\
\hline \multicolumn{6}{|l|}{ Spacing $(\mathrm{cm})$} \\
\hline $20 \times 60$ & 4.41 & $7.23^{\mathrm{b}}$ & $9.04^{\mathrm{b}}$ & $12.10^{\mathrm{b}}$ & $13.30^{\mathrm{b}}$ \\
\hline $25 \times 60$ & 4.49 & $7.04^{\mathrm{a}}$ & $9.18^{\mathrm{a}}$ & $12.04^{\mathrm{b}}$ & $13.21^{\mathrm{b}}$ \\
\hline $30 \times 60$ & 4.51 & $7.62^{\mathrm{a}}$ & $9.26^{\mathrm{a}}$ & $12.28^{\mathrm{a}}$ & $13.47^{\mathrm{a}}$ \\
\hline LS & NS & $* *$ & $* *$ & $*$ & $* *$ \\
\hline $\mathrm{SE} \pm$ & 0.06 & 0.04 & 0.04 & 0.06 & 0.06 \\
\hline \multicolumn{6}{|l|}{ Year } \\
\hline 2018 & $4.08^{b}$ & $6.78^{\mathrm{b}}$ & $8.76^{\mathrm{b}}$ & $11.73^{b}$ & $12.93^{\mathrm{b}}$ \\
\hline 2019 & $4.86^{\mathrm{a}}$ & $7.58^{\mathrm{a}}$ & $9.56^{\mathrm{a}}$ & $12.54^{\mathrm{a}}$ & $13.72^{\mathrm{a}}$ \\
\hline LS & NS & $* *$ & $* *$ & $*$ & $* *$ \\
\hline $\mathrm{SE} \pm$ & 0.05 & 0.04 & 0.03 & 0.05 & 0.05 \\
\hline \multicolumn{6}{|l|}{ Interaction } \\
\hline PxS & NS & NS & NS & NS & NS \\
\hline PxY & $* *$ & NS & NS & NS & NS \\
\hline SxY & NS & NS & NS & NS & NS \\
\hline PxSxY & NS & NS & NS & NS & NS \\
\hline
\end{tabular}

LS $=$ Level of significance, $\mathrm{SE}=$ Standard error, $\mathrm{NS}=$ not significant, ${ }^{* *}=$ significance at 0.01 ,

Means followed by same letter in a column are statistically similar by DMRT. 
Table 3. Interaction of phosphorous and year on number of branches of groundnut at 4 WAS

\begin{tabular}{ccc}
\hline & \multicolumn{2}{c}{ Year } \\
\cline { 2 - 3 } Phosphorous $(\mathrm{kg} / \mathrm{ha})$ & 2018 & 2019 \\
\hline 0 & $3.74^{\mathrm{d}}$ & $4.21^{\mathrm{c}}$ \\
30 & $4.32^{\mathrm{c}}$ & $4.72^{\mathrm{b}}$ \\
60 & $4.46^{\mathrm{bc}}$ & $5.21^{\mathrm{a}}$ \\
90 & $3.80^{\mathrm{d}}$ & $5.31^{\mathrm{a}}$ \\
LS & $* *$ & \\
SE \pm & 0.10 & \\
\hline
\end{tabular}

$\mathrm{LS}=$ Level of significance, $\mathrm{SE}=$ Standard error, NS = not significant, $* *$ = significance at 0.01 ,

Means followed by same letter in a column are statistically similar by DMRT.

\subsection{Canopy spread}

The results as presented in Table 4 revealed a significant difference among various treatments used for canopy spread. The results further indicated that, except at 4 WAS where $90 \mathrm{~kg}$ produced wider canopy, application of 60 and $90 \mathrm{~kg} / \mathrm{ha}$ were statistically at par but significantly better than the other rates and all the rates were better than the control. The significant difference observed in this study could be a result of increased availability of the nutrient in the soil which increases the rate of solar interception by the canopy. The result of this study is in agreement with the findings of [12] who reported that canopy width increases with the increase in phosphorus fertilizer rate, where maximum canopy width was recorded in the highest phosphorus application rates. The result of this study also lends its support to the findings of [13] who indicated that, increase in phosphorus fertilizer application led to an increase in canopy size of groundnut.

The study on spacing showed that, wider spacing consistently produced significantly broader canopy throughout the study period. However, closest spacing significantly reduced canopy spread in both years under investigation. Result of interaction (Table 5) revealed that, application of 60 and $90 \mathrm{~kg}$ P/ha to groundnut spaced at 25 and $30 \times 60 \mathrm{~cm}$ gave better canopy spread than closer spacing. This could be due to low competition between the plants as closer spacing increases competition among the plants. This is in line with the report of [14] who affirmed that, wide spacing produced well spread canopy than closer spacing.

Study on year effect indicated that, except at 10 WAS where no significant difference was observed, 2019 produced better canopy cover than 2018. Study on interaction (Table 6) revealed that, application of 60 and $90 \mathrm{~kg} \mathrm{P} / \mathrm{ha}$ in 2019 gave better canopy spread than in 2018. This could be due to increase in soil $\mathrm{pH}$ as the organic matter added to the soil by groundnut leaves in the previous season increases the soil $\mathrm{pH}$ which in turn reduced phosphorous fixation and increased its availability in the soil. This is in conformity with the report of [13] who affirmed that, lower pH leads to phosphorous fixation and rendered its unavailable in the soil. 
Table 4. Effects of phosphorus fertilization and plant spacing on canopy spread (cm) of groundnut

\begin{tabular}{|c|c|c|c|c|c|}
\hline \multirow[b]{2}{*}{ Treatments } & \multicolumn{5}{|c|}{ WAS } \\
\hline & 4 & 6 & 8 & 10 & 12 \\
\hline \multicolumn{6}{|c|}{ Phosphorous (kg/ha) } \\
\hline 0 & $10.48^{\mathrm{d}}$ & $14.67^{\mathrm{c}}$ & $19.87^{\mathrm{c}}$ & $25.89^{\mathrm{c}}$ & $28.99^{b}$ \\
\hline 30 & $11.69^{\mathrm{c}}$ & $17.06^{\mathrm{b}}$ & $22.22^{b}$ & $28.14^{\mathrm{b}}$ & $29.62^{b}$ \\
\hline 60 & $13.76^{\mathrm{b}}$ & $19.58^{\mathrm{a}}$ & $24.54^{\mathrm{a}}$ & $29.79^{\mathrm{a}}$ & $31.63^{\mathrm{a}}$ \\
\hline 90 & $13.96^{\mathrm{a}}$ & $19.51^{\mathrm{a}}$ & $24.81^{\mathrm{a}}$ & $28.58^{\mathrm{b}}$ & $32.64^{\mathrm{a}}$ \\
\hline LS & $* *$ & $* *$ & $* *$ & $* *$ & $* *$ \\
\hline $\mathrm{SE} \pm$ & 0.04 & 0.14 & 0.15 & 0.36 & 0.37 \\
\hline \multicolumn{6}{|l|}{ Spacing $(\mathrm{cm})$} \\
\hline $20 \times 60$ & $12.56^{\mathrm{b}}$ & $17.41^{b}$ & $21.67^{\mathrm{c}}$ & $26.35^{\mathrm{b}}$ & $28.18^{\mathrm{c}}$ \\
\hline $25 \times 60$ & $12.38^{\mathrm{ab}}$ & $17.85^{\mathrm{a}}$ & $22.93^{\mathrm{b}}$ & $28.59^{\mathrm{a}}$ & $30.83^{b}$ \\
\hline $30 \times 60$ & $12.48^{\mathrm{a}}$ & $17.86^{\mathrm{a}}$ & $23.98^{\mathrm{a}}$ & $29.37^{\mathrm{a}}$ & $33.16^{\mathrm{a}}$ \\
\hline LS & $* *$ & $*$ & $* *$ & $*$ & $* *$ \\
\hline $\mathrm{SE} \pm$ & 0.04 & 0.12 & 0.13 & 0.31 & 0.32 \\
\hline \multicolumn{6}{|l|}{ Year } \\
\hline 2018 & $12.23^{\mathrm{b}}$ & $16.90^{\mathrm{b}}$ & $21.86^{\mathrm{b}}$ & 27.79 & $30.11^{\mathrm{b}}$ \\
\hline 2019 & $12.73^{\mathrm{a}}$ & $18.51^{\mathrm{a}}$ & $23.86^{\mathrm{a}}$ & 28.41 & $31.33^{\mathrm{a}}$ \\
\hline LS & $* *$ & $* *$ & $* *$ & NS & $* *$ \\
\hline $\mathrm{SE} \pm$ & 0.03 & 0.10 & 0.11 & 0.25 & 0.26 \\
\hline \multicolumn{6}{|l|}{ Interaction } \\
\hline PxS & NS & NS & $*$ & NS & NS \\
\hline PxY & NS & NS & NS & $* *$ & $* *$ \\
\hline SxY & NS & NS & NS & NS & NS \\
\hline PxSxY & NS & NS & NS & NS & NS \\
\hline
\end{tabular}

$\mathrm{LS}=$ Level of significance, $\mathrm{SE}=$ Standard error, $\mathrm{NS}=$ not significant,$* *=$ significance at 0.01 , Means followed by same letter in a column are statistically similar by DMRT.

Table 5. Interaction of phosphorous and spacing on canopy spread of groundnut at 8 WAS

\begin{tabular}{cccc}
\hline & & Spacing & $30 \times 60$ \\
\cline { 2 - 4 } Phosphorous (kg/ha) & $20 \times 60$ & $25 \times 60$ & $21.50^{\text {cd }}$ \\
\hline 0 & $18.47^{\mathrm{f}}$ & $19.63^{\mathrm{e}}$ & $23.67^{\mathrm{b}}$ \\
30 & $20.95^{\mathrm{d}}$ & $22.03^{\mathrm{c}}$ & $25.17^{\mathrm{a}}$ \\
60 & $23.47^{\mathrm{b}}$ & $25.00^{\mathrm{a}}$ & $25.57^{\mathrm{a}}$ \\
90 & $23.78^{\mathrm{b}}$ & $25.07^{\mathrm{a}}$ & \\
LS & $*$ & \\
SE \pm & & 0.26 & \\
\hline
\end{tabular}

LS = Level of significance, $\mathrm{SE}=$ Standard error, $\mathrm{NS}=$ not significant, $* *=$ significance at 0.01 ,

Means followed by same letter in a column are statistically similar by DMRT. 
Table 6. Interaction of phosphorous and year on canopy spread of groundnut at 10 and 12 WAS

\begin{tabular}{ccccc}
\hline & \multicolumn{2}{c}{ Year } & \multicolumn{2}{c}{12 WAS } \\
\cline { 2 - 5 } Phosphorous (kg/ha) & 2018 & 2019 & 2019 & 2019 \\
\hline 0 & $26.32^{\mathrm{de}}$ & $25.47^{\mathrm{e}}$ & $29.49^{\mathrm{de}}$ & $28.50^{\mathrm{e}}$ \\
30 & $28.44^{\mathrm{bc}}$ & $27.84^{\mathrm{cd}}$ & $28.50^{\mathrm{e}}$ & $30.74^{\mathrm{cd}}$ \\
60 & $29.74^{\mathrm{ab}}$ & $29.83^{\mathrm{ab}}$ & $30.64^{\mathrm{cd}}$ & $32.61^{\mathrm{ab}}$ \\
90 & $26.66^{\mathrm{de}}$ & $30.50^{\mathrm{a}}$ & $31.81^{\mathrm{bc}}$ & $33.48^{\mathrm{a}}$ \\
LS & & $* *$ & $* *$ & 0.53 \\
\hline
\end{tabular}

$\mathrm{LS}=$ Level of significance, $\mathrm{SE}=$ Standard error, $\mathrm{NS}=$ not significant, $* *=$ significance at 0.01 , Means followed by same letter in a column are statistically similar by DMRT.

\subsection{Biomass yield}

Table 7 presented result on the effects of phosphorous fertilization, plant spacing and year on biomass yield of groundnut. The result showed that, there is a significant difference among various levels of phosphorous used throughout the study period. The result also indicated that, application of 60 and $90 \mathrm{~kg} / \mathrm{ha}$ produced statistically similar biomass yield, but significantly better than the other rates and all the rates were better than the control. The significant difference observed in this study indicated the importance of phosphorous fertilizer in biomass yield of groundnut. The result of this experiment is in conformity with the findings of [15] who reported that, phosphorus application brought about significant increase in biological yield of groundnut. This result also corroborates the findings of [9] who reported a similar trend while studying phosphorous fertilization in groundnut production.

Considering spacing however, a significant difference was observed throughout the study period on biomass yield. Based on the result observed, closer spacing gave significantly highest biological yield than the wider spacing used. This could be due to higher number of plants per hectare as opposed to wider spacing with lower number of stand. The result of the present study is in agreement with the previous findings by [11] who reported that, the higher planting density produced superior biomass yield of groundnut than the lower density. Study on year effect on the hand, showed that the two sessions were statistically similar in terms of biomass yield. This indicated that biomass yield of groundnut was not affected by season. This is not in line with the report of [12] who said that, biomass yield of groundnut showed a significant response to seasonal changes. 
Table 7. Effects of phosphorus fertilization and plant spacing on biomass, stover and pod yield yield of groundnut

\begin{tabular}{|c|c|c|c|}
\hline \multirow[b]{2}{*}{ Treatments } & \multicolumn{3}{|c|}{ Parameters (kg/ha) } \\
\hline & Stover yield & Biomass yield & Pod yield \\
\hline \multicolumn{4}{|c|}{ Phosphorous (kg/ha) } \\
\hline 0 & $1914.11^{\mathrm{c}}$ & $2902.17^{\mathrm{c}}$ & $1299.21^{\mathrm{c}}$ \\
\hline 30 & $2233.69^{b}$ & $3465.81^{b}$ & $1773.90^{\mathrm{b}}$ \\
\hline 60 & $2714.48^{\mathrm{a}}$ & $4106.04^{\mathrm{a}}$ & $2164.28^{\mathrm{a}}$ \\
\hline 90 & $2755.34^{\mathrm{a}}$ & $4285.25^{\mathrm{a}}$ & $2207.11^{\mathrm{a}}$ \\
\hline LS & $* *$ & $* *$ & $* *$ \\
\hline $\mathrm{SE} \pm$ & 23.24 & 74.72 & 34.86 \\
\hline \multicolumn{4}{|l|}{ Spacing $(\mathrm{cm})$} \\
\hline $20 \times 60$ & $2846.27^{\mathrm{a}}$ & $4367.16^{\mathrm{a}}$ & $2242.54^{\mathrm{a}}$ \\
\hline $25 \times 60$ & $2355.61^{\mathrm{b}}$ & $3616.49^{b}$ & $1855.14^{\mathrm{b}}$ \\
\hline $30 \times 60$ & $2011.48^{\mathrm{c}}$ & $3085.80^{\mathrm{c}}$ & $1485.70^{c}$ \\
\hline LS & $* *$ & $*$ & $* *$ \\
\hline $\mathrm{SE} \pm$ & 22.72 & 64.71 & 30.19 \\
\hline \multicolumn{4}{|l|}{ Year } \\
\hline 2018 & 2399.61 & 3656.07 & 1830.99 \\
\hline 2019 & 2409.29 & 3723.57 & 1891.27 \\
\hline LS & NS & NS & NS \\
\hline $\mathrm{SE} \pm$ & 18.55 & 52.84 & 24.65 \\
\hline \multicolumn{4}{|l|}{ Interaction } \\
\hline $\mathrm{PxS}$ & NS & NS & $* *$ \\
\hline $\mathrm{PxY}$ & NS & NS & NS \\
\hline SxY & NS & NS & NS \\
\hline PxSxY & NS & NS & NS \\
\hline
\end{tabular}

$\mathrm{LS}=$ Level of significance, $\mathrm{SE}=$ Standard error, $\mathrm{NS}=$ not significant,$* *=$ significance at 0.01, Means followed by same letter in a column are statistically similar by DMRT.

\subsection{Stover yield}

The results in Table 7 showed that, phosphorous fertilization had a significant effect on stover yield throughout the study period. The results further revealed that, application of 60 and $90 \mathrm{~kg} \mathrm{P} /$ ha produced statistically similar results but significantly better than the other rates. The higher response to phosphorous fertilization observed in this study could be as a results of lower phosphorous level in the experimental site. This is in agreement with the report of [12] who reported that, response to phosphorous fertilization could be obtained when the available $\mathrm{P}$ status in the soil was less than $35 \mathrm{~kg} \mathrm{P}_{2} \mathrm{O}_{5} /$ ha. The results of this findings is also in support of the result of [15] who reported that, phosphorus fertilizer plays a beneficial role in legume growth, promoting extensive root development and thereby ensuring a good yield. The result of this findings is not in line with the report of [9] who opined that, phosphorous fertilization had no significant effect on stover yield.

On the other hand, closer spacing produced significantly higher stover yield than the other spacings used. The significant difference observed in this study could be due to higher number of plants per hectare as opposed to wider spacing with lower number of stands. The result of this findings lends its support from the findings of [11] who noted that growth and branching of groundnut are reduced at higher population densities.

Study on year effect on the hand showed that, the two sessions produced statistically similar stover yield. This indicated that stover yield of groundnut was not affected by season. This is not in agreement with the report of [12] who 
said that, stover yield of groundnut shows a significant response to seasonal changes.

\subsection{Pod yield}

Table 7 also presented results on the effect of phosphorous fertilization, plant spacing and year on pod yield of groundnut. The results revealed that, application of 60 and $90 \mathrm{~kg}$ P/ha were statistically at par but significantly better than the other rates in promoting pod yield of groundnut. This indicated the importance of phosphorous application to pod yield of groundnut. It could also be due to higher number of branches, wider canopy with well-structured leaves for better solar interception. The result of this findings lends support from the findings of [13] who reported that, phosphorous application enhances number of branches and promotes canopy spread leading to higher number of pods in groundnut.

Spacing on the other hand, the results revealed that, higher pod yield was obtained at closer than the wider spacings. Interaction of phosphorous and spacing on pod yield of groundnut (Table 8) revealed that, application of 60 and $90 \mathrm{~kg} \mathrm{P} / \mathrm{ha}$ to groundnut spaced at $20 \times 60 \mathrm{~cm}$ produced the higher pod yield than the other treatments combination. This could be due to better ground cover and reduced competition by weeds, as better canopy cover shade the weed and reduced their competitive ability. Similarly the closer the spacing, the higher the number of stand and the higher the number of pods produced. The result of this findings is in conformity with the findings of [5] who obtained a similar result while studying spacing and fertilizer application on peanut.

Table 8. Interaction of phosphorous and spacing on pod yield of groundnut

\begin{tabular}{cccc}
\hline & & Spacing & \\
\cline { 2 - 4 } Phosphorous (kg/ha) & $20 \times 60$ & $25 \times 60$ & $30 \times 60$ \\
\hline 0 & $1629.10^{\mathrm{d}}$ & $1160.77^{\mathrm{f}}$ & $1107.77^{\mathrm{f}}$ \\
30 & $2127.77^{\mathrm{b}}$ & $1837.50^{\mathrm{c}}$ & $1356.43^{\mathrm{e}}$ \\
60 & $2589.32^{\mathrm{a}}$ & $2174.80^{\mathrm{b}}$ & $1728.73^{\text {cd }}$ \\
90 & $2623.97^{\mathrm{a}}$ & $2247.50^{\mathrm{a}}$ & \\
LS & & $* *$ & \\
SE \pm & & 60.38 & \\
\hline
\end{tabular}

LS = Level of significance, $\mathrm{SE}=$ Standard error, $\mathrm{NS}=$ not significant, $* *=$ significance at 0.01 ,

Means followed by same letter in a column are statistically similar by DMRT.

\section{Conclussion and recommendation}

Based on the result of these findings, it was observed that phosphorous status of the study area was low and phosphorous fertilization had a direct effect on the herbage yield of groundnut. However, closer spacing produced higher herbage yield of groundnut than the wider spacing. Therefore, for good herbage production of groundnut the application of 60 to $90 \mathrm{~kg}$ P/ha and a spacing of $20 \times 60 \mathrm{~cm}$ should be adopted by farmers in the study area.

\section{Conflict of interest declaration}

The authors of this article declared that there is no conflict of interest.

\section{References}

[1] Dokli DK. Studies on improved groundnut varieties: Intercropping with maize and response to phosphate fertilizer. 
Field Crops Research. 2007; 26(4): 263-277.

[2] Garba AB, Auwalu M and Abdul SD. Effect of variety and intra-row spacing on flower production in groundnut under the prevailing weather conditions of the Northern Guinea Savanna. Nigerian Journal of Agricultural Technology. 2002; 10(2): 19-27

[3] National Bureau of Statistics of the Federal Republic of Nigeria. 2019 Agricultural production report. 2019.

[4] Agasimani CA. Response of groundnut cultivars to different spacing. Indian Journal of Agronomy. $2007 ; 4$ : 60-70.

[5] Hameed-Ansari A, Qauym SM and Usman MUK. Impact of row spacing and NPK fertilizer levels on the growth, seed yield and seed oil content in peanut (Arachis hypogaea). Oil Crops. 2007; 20: 234-245.

[6] Oudhia P. Allelopathic effects of weeds on crops. Research Journal of Agriculture and Biological Sciences. 2003; 3(1): 52-58.

[7] Subrahmaniyan K, Kalaiselvan P, Manickam G and Arulmozhi N. Spacing and fertilizer requirement for confectionary groundnut varieties. Crop Research. 2000; 19: 210-212.

[8] Ahmad N, Mohammad K. Evaluation of different varieties, seed rates and row spacing of groundnut under agroecological conditions of Malakand Division. Agronomy. 2007; 6(2): 12-22.

[9] Fagam AS, Shuaibu YM, Garba AA and Theoplus TK. Herbage yield of groundnut as influenced by phosphorous levels and intra-row spacing in Bukuru Plateau state, Nigeria. Nigerian journal of Agricultural and development economics. 2015; 5(2): 59-66.

[10] Kathirvelan P, Kalaiselvan P. Studies on agro management techniques for confectionery groundnut under irrigated conditions. Research Journal of Agriculture and Biological Sciences. 2007; 23(1): 152-159.

[11] John OS. Growth and yield response of groundnut (Arachis hypogaea L.) to plant densities and phosphorus on an ultisol in southeastern Nigeria. Libyan Agriculture Research Center Journal International. 2010; 1(4): 211-214.

[12] Shuaibu YM, Kawure S and Bala RA. Effect of season, variety and phosphorus fertilization on the growth and yield of groundnut (Arachis hypogaea L.) in Bauchi State Nigeria. Journal of Horticulture and Plant Research. 2019; 6: 20-26.

[13] Fagam AS, Shuaibu YM, Garba AA, Theoplus TK and Kawure S. Influence of phosphorous levels and intrarow spacing on yield and yield components of groundnut in Bukuru Plateau state, Nigeria. Nigerian journal of Agricultural and development economics. 2016; 6(1): 185-193.

[14] Shuaibu YM, Kawure S and Bala RA. Influence of Season, Variety and Phosphorus Fertilization on Herbage Yield of Groundnut (Arachis hypogaea L.) in Bauchi State Nigeria. Sustainable Food Production. 2019; 5: 1-5.

[15] Chandrasekaran R, Somasundaram E, Mohamed Amanullah M, Thirukumaran K and Sathyamoorthi K. Influence of varieties and plant spacing on the growth and yield of confectionery groundnut (arachis hypogaea l.). Research Journal of Agriculture and Biological Sciences. 2007; 3(5): 525-528. 